\title{
Analyses of combat-related injuries to the maxillofacial and cervical regions and experiences in an operational field hospital
}

\author{
Mehmet Burak Aşık, M.D., ${ }^{1}$ Sinan Akay, M.D., ${ }^{2}$ Sami Eksert, M.D. ${ }^{3}$ \\ 1'Department of Otolaryngology and Head\& Neck Surgery, Gülhane Training and Research Hospital, Ankara-Turkey \\ ${ }^{2}$ Department of Radiology, Dr. Aşkım Tüfekçi State Hospital, Adana-Turkey \\ ${ }^{3}$ Department of Anesthesiology and Reanimation, Gülhane Research and Training Hospital, Ankara-Turkey
}

\begin{abstract}
BACKGROUND: With the changing conditions of war, maxillofacial injuries are observed more frequently. Particularly in urban areas, high-energy explosive devices (HEEDs), such as improvised explosive devices, are often used alongside long-barreled weapons (LBWs). It is important to use trauma scoring systems and a multidisciplinary approach for medically and accurately responding to the trauma patient in a timely manner. This study aimed to compare the Military Combat Injury Scale (MCIS) and Military Functional Incapacity Scale (MFIS) between injuries sustained by LBWs or HEEDs and to share experiences of an operational field hospital.

METHODS: Medical data of 84 patients admitted to an operational field hospital with maxillofacial and cervical injuries sustained by LBWs and HEEDs between July 27, 20I5, and July 22, 2016 were reviewed. MCIS and MFIS scores were calculated for all patients; records of the qualifying patients were studied for the Glasgow Coma Scale (GCS) scores and injury sites. The patients were divided into two groups according to the device/weapon causing the injury: injuries sustained by LBWs in group I and those sustained by HEEDs in group II.
\end{abstract}

RESULTS: All patients were males, with a mean age of 28.75 (range 20-58) years. The average GCS score was I3.4, but it was lower than 15 in 16 (19\%) of the patients. There was no statistically significant difference in MCIS scores between the LBW and HEED groups $(p=0.206)$. In addition, there was no statistically significant difference in MFIS scores between the LBW and HEED groups ( $p=0.238)$.

CONCLUSION: Maxillofacial and cervical region injuries are increasing in modern conflicts that are usually located in urban areas. Injuries sustained by HEEDs as well as those sustained by LBWs in the maxillofacial area are morbid and mortal. Rapid and comprehensive intervention is life-saving and helping the patient to further trauma treatment.

Keywords: High-energy explosive device; maxillofacial trauma; trauma; trauma scoring system.

\section{INTRODUCTION}

Maxillofacial and cervical injuries are common in both civilian and military trauma settings. The importance of having specialized surgeons to deal with the head, face, and neck was observed during the First World War. ${ }^{[1]}$ More recently, Dobson et al. ${ }^{[2]}$ noted that head and neck injuries are more common during terrorist attacks than during conventional modern warfare. Recent literature from the contemporary theaters of conflict in Iraq and Afghanistan has reported an increase in maxillofacial injuries, ranging from $26 \%$ to $36 \%$. $^{[3,4]}$ This increase may be influenced by the use of modern combat body armor and nature of asymmetrical warfare in urban areas. According to Kosashvili et al.," ${ }^{[5]}$ even with modern body armor, the maxillofacial and cervical region has the highest rate of penetrating wounds from shrapnel, creating a vulnerable anatomical area. Overall, the incidence of penetrating head and neck trauma has been increasing in modern combat.

Cite this article as: Aşı MB, Akay S, Eksert S. Analyses of combat-related injuries to the maxillofacial and cervical regions and experiences in an operational field hospital. Ulus Travma Acil Cerrahi Derg 2018;24:56-60

Address for correspondence: Mehmet Burak Aşık, M.D.

Gülhane Eğitim ve Araştırma Hastanesi, KBB ve Baş-Boyun Cerrahisi Kliniği, Ankara, Turkey.

Tel: +90 312 - 3045710 E-mail: burock312@yahoo.com

Ulus Travma Acil Cerrahi Derg 2018;24(I):56-60 DOI: 10.5505/tites.2017.75333 Submitted: 17.03.2017 Accepted: 12.05.2017

Copyright 2018 Turkish Association of Trauma and Emergency Surgery 
The body armor currently employed effectively protects the chest and abdomen, but leaves the face and neck exposed, resulting in a shift toward increased head and neck injuries. ${ }^{[5,6]}$

Major causes of facial combat injuries include blasts, high-velocity/high-energy missiles, and low-velocity missiles. Blasts caused by high-energy explosive devices (HEEDs) [improvised explosive devices (IEDs), projectile missiles, etc.] often contain metal fragments, with hundreds of metal pellets. [2,6] Those combatants who are closest to the explosion are exposed to morbid and mortal injuries. ${ }^{[6]}$ Moreover, longbarreled weapon (LBW) injuries to the face and neck often create major resuscitation and surgical problems. In the case of an injury sustained by LBW to the face, early operative management of the injured soft and skeletal tissues of the face is related to less morbidity and mortality. ${ }^{[7]}$

Early evacuation of the injured patient to an operational field hospital to undergo a multidisciplinary approach for trauma is a vital part of the treatment for patients who have suffered from ballistic trauma. The main areas in which disputes do exist are the surgical timing, necessity of surgery, and trauma evaluation.

This study aimed to compare the Military Combat Injury Scale (MCIS) and Military Functional Incapacity Scale (MFIS) severity scores of maxillofacial and cervical injuries due to LBWs and HEEDs in a combat area. In addition, injury patterns and demographic data of the patients admitted to the emergency department of an operational field hospital were reviewed.

\section{MATERIALS AND METHODS}

Review board approval was obtained for this retrospective study. Medical data of 84 patients admitted to an operational field hospital with maxillofacial and cervical injuries from LBWs and HEEDs between July 27, 20I5, and July 22, 2016, were reviewed. Cases were gathered during military operations against terrorist groups in the southeastern part of Turkey, and all patients were soldiers or police officers. MCIS and MFIS scores were calculated for all patients, and records of the qualifying patients were studied for the Glasgow Coma Scale (GCS) scores and injury sites. The patients were divided into two groups according to the device/weapon causing the injury: injuries caused by LBWs in group I and those caused by HEEDs in group II.

The injury sites were sorted by and defined anatomically as the upper third of the face, middle third of the face, lower third of the face, and cervical region. The extent of the injury was graded according to MCIS as follows: I = minor, 2 = moderate, 3 = serious, $4=$ severe, and $5=$ likely lethal. ${ }^{\left[{ }^{[8}\right.}$ In this study, the patients were also evaluated according to MFIS as follows: $\mathrm{I}$ = able to continue mission, 2 = able to contribute to sustaining the mission, $3=$ lost to mission, and $4=$ lost to military. ${ }^{[8]} \mathrm{MCIS}$ and MFIS scores are shown in Table I and 2.
Table I. Components of the Military-spesific Combat Injury Scale (MCIS)

\begin{tabular}{ll}
\hline MCIS Injury Severity Score & Description \\
\hline I & Minor \\
2 & Moderate \\
3 & Serious \\
4 & Severe \\
5 & Likely Lethal \\
\hline
\end{tabular}

Table 2. Components of the Military Functional Incapacity Scale

\begin{tabular}{lcl}
\hline Associated MCIS Score & MFIS Score & Description \\
\hline I & I & $\begin{array}{l}\text { Able to continue mission } \\
2\end{array}$ \\
& 2 & $\begin{array}{l}\text { Able to contribute to } \\
\text { sustaining mission }\end{array}$ \\
$3-4$ & 3 & Lost to mission \\
$4-5$ & 4 & Lost to military \\
\hline
\end{tabular}

MCIS: Military Combat Injury Scale; MFIS: Military Functional Incapacity Scale.

\section{Statistical Analysis}

Gathered data were analyzed using SPSS 15.0 software for Windows (IBM, Chicago, Illinois, USA). Variables were investigated using visual methods (histograms and probability plots) and analytical methods (Kolmogorov-Smirnov and Shapiro-Wilk's tests) to determine whether or not they were distributed normally. The descriptive analyses were presented using the mean \pm standard deviation for normally distributed variables. The Student's t-test was used to compare these parameters between MCIS severity scores and MFIS scores of patients who have suffered from trauma due to HEED and LBW. A p-value of $<0.05$ was considered to show a statistically significant result.

\section{RESULTS}

\section{Severity Scores}

Eighty-four patients were included in this study. All patients were males, with a mean age of 28.75 (range, 20-58) years. The average GCS score was 13.4 , but it was lower than 15 in $16(19 \%)$ of the patients. The mean MCIS score was 1.91 , the median was 2 , and there was no statistically significant difference between the LBW and HEED groups $(p=0.206)$ (Table 3). The mean MFIS score was I.85, the median was I, and there was no statistically significant difference between the LBW and HEED groups $(p=0.238)$ (Table 3$)$.

\section{Injury Pattern}

Of the patients with injuries isolated only to the face, $40 \%$ $(n=20)$ were injuries sustained by HEEDs and $73 \%(n=25)$ 
were those sustained by LBWs in a total of 45 patients. In injuries sustained by HEEDs, the most commonly associated cervicofacial region was the middle third of the face, which was injured in $23 / 50$ patients (46\%), whereas the upper third of the face was affected in 13/50 HEED patients (26\%). In injuries sustained by LBWs, the most commonly associated cervicofacial region was the cervical region, which was injured in 14/34 patients (4I\%). The least frequently fractured bony complex in the patients in the HEED group was the mandibula (eight cases) (16\%), whereas the upper I/3 and the middle I/3 parts of the face (six cases for each) (I7\%) were the least commonly fractured bony complexes of the cervicofacial region in the LBW group. Table 4 shows the injury site and causation totals.

\section{Surgical Workload}

Seventy-nine of the patients with cervicofacial injuries sustained by HEEDs or LBWs survived (94\%). The mean and median MCIS severity scores of the decedents $(n=5)$ with multiple injury sites, particularly the thorax and head, were both 4 . In the decedents, the mean Abbreviated Injury Scale (AIS) score was $4.6(3,4,6,6$, and 4 for the five patients, respectively), with one patient among these in whom the MCIS score was 2 and the AIS score was 3. Two of the decedents were injured by LBWs and three were injured by HEEDs. The mean AIS score of the survivors was I.3 (median I), with one unexpected survivor with an AIS score of 5 .

Maxillofacial or cervical surgeries were required in $39 \%$ $(n=33)$ of the 84 patients with cervicofacial injuries at the operational field hospital. Sixteen of these 33 patients required surgical interventions under general anesthesia for primarily

Table 3. Distribution of cases according to their Militaryspecific Combat Injury Scale and Military-specific Functional Injury Scale

\begin{tabular}{lcccc}
\hline & Number of cases & MCIS & & MFIS \\
\cline { 3 - 3 } & & Mean \pm SD & & Mean \pm SD \\
\hline LBW & 34 & $2.08 \pm 1.16$ & & $2.01 \pm 1.01$ \\
HEED & 50 & $1.80 \pm 0.90$ & & $1.76 \pm 0.82$ \\
Total & 84 & $1.91 \pm 1.02$ & & $1.85 \pm 0.91$
\end{tabular}

MCIS: Military-spesific Combat Injury Scale; MFIS: Military Functional Incapacity Scale; LBW: Long barreled weapon; HEED: High-energy explosive device; SD: Standard deviation.

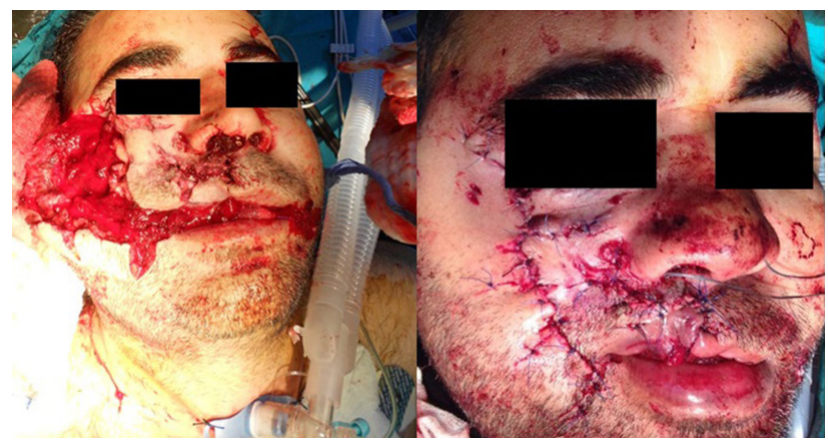

Figure 1. Maxillomandibular fracture. Image of bleeding control, soft tissue repair, and tracheotomy.

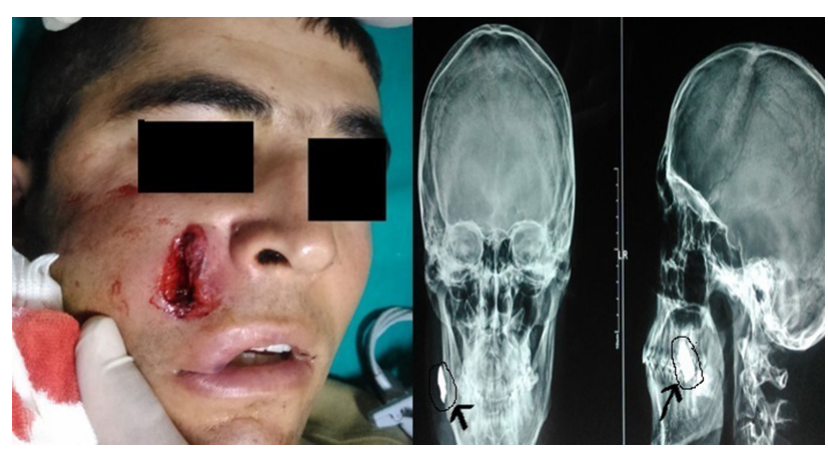

Figure 2. Image of the intrabuccal region sharpnel. Excision of the shrapnel from the face and primary soft tissue repair was performed.

bleeding control, soft tissue repair, airway security, and maxillofacial reconstruction (Fig. I). Surgeries were performed in 17 patients for minimal bleeding control, excision of shrapnel from the face, and debridement or primary soft tissue repair of cervicofacial wounds (Fig. 2). Of these, only 12 required additional reconstructive surgery and were evacuated to an advanced hospital for further treatment.

Thirty-seven patients ( $46 \%$ of the survivors) with minor injuries were discharged from the field hospital and returned to military duty. Thirty patients were discharged for a period of rest because of other medical problems. Hospitalization was necessary in $83 \%(n=70)$ of the patients, with $17 \%(n=12)$ of the hospitalized patients requiring stays in the intensive care unit.

\section{DISCUSSION}

Although AIS is the most commonly used trauma scoring system by injury researchers, MCIS and MFIS, which were described by Lawnick et al. ${ }^{[8]}$ in 2013 , are currently and increas-

Table 4. Distribution of maxillofacial injuries according to the injury pattern and their localization

\begin{tabular}{lccccc}
\hline & Upper I/3 of face & Middle I/3 of face & Lower I/3 of face & Cervical & Total \\
\hline Long barreled weapon & 6 & 6 & 8 & 34 \\
High-energy explosive device & 13 & 23 & 8 & 14 & 6 \\
Total & 19 & 29 & 16 & 22 & 84 \\
\hline
\end{tabular}


ingly used for classifying and defining military-related injuries. [9] Lawnick et al. ${ }^{[8]}$ noted that MCIS showed superior performance compared with AIS because its source was rooted in combat injury databases. In addition, Wordsworth et al. ${ }^{[10]}$ concluded that AIS cannot predict the need for reconstructive surgery for combat-related maxillofacial injuries. The development of MCIS and MFIS included five combat body regions, injury severity along a five-point scale, injury descriptions for a spectrum of combat-related injuries, and injury description codes. ${ }^{[8]}$ Moreover, MFIS was based on military functional capacity in a process relevant to MCIS. Despite this previous research, there remains a controversy with regard to which is the best trauma scoring scale.

In the present study, it was concluded that the combat-related maxillofacial and cervical HEED injury severity scores were as high as the LBW injury severity scores. There was no statistically significant difference between the HEED and LBW groups with regard to MCIS scores $(p=0.206)$. Wordsworth et al. ${ }^{[10]}$ concluded that the maxillofacial region is commonly injured during blasts. Similarly, in this study on modern conflicts, which occur in narrow places and near urban areas, maxillofacial and cervical injuries are commonly observed because of the use of HEEDs like IEDs. Therefore, maxillofacial and cervical injuries sustained by HEEDs are as important as injuries sustained by LBWs. In addition, there was no significant difference between injuries sustained by HEED and those sustained by LBWs with regard to MFIS scores $(p=0.238)$. Injuries sustained by both HEEDs and by LBWs decreased functional capacities of the combatants in the combat area. Moreover, there were few publications evaluating trauma scoring and comparing maxillofacial and cervical injuries sustained by HEEDs and LBWs in the literature.

The results of this study showed that more than half of the injuries sustained to the cervicofacial region from a blast or penetrating injuries were relatively minor and managed by a single procedure in the field hospital. We also found that in the patients with trauma sustained by HEEDs, the maxilla was the most frequently fractured bony complex. However, the cervical region was the most injured region of the face and neck in injuries sustained by LBWs. This difference could be explained by the ballistic rules and the use of a ballistic guard apparatus. In HEED explosions, the upper and lower thirds of the face are protected with a ballistic helmet and a reflexive maneuver of the neck to avoid the blast. Therefore, the blast eruption and materials directly affect the middle third of the face. Similarly, Levin et al. ${ }^{[1]}$ reported that most battlefield injuries in their study (44\%) also involved the maxilla. Moreover, Breeze et al. ${ }^{[2]}$ and Feldt et al. ${ }^{[13]}$ found that the maxilla sustained the most injuries in their studies on $>15,000$ patients who had suffered from trauma. When an injury is sustained by an LBW (gunshot), there is no time to react with an avoidance maneuver and no guard apparatus for the neck. Therefore, the overall mortality rate was $6 \%$ $(n=5)$, and our findings suggested that mortality was asso- ciated with systemic or complex injuries. In our study, no deaths occurred from isolated cervicofacial combat-related injuries. Similar to our results, Norris et al. ${ }^{[14]}$ found that systemic injuries, rather than isolated facial injuries, affected the mortality rate.

Much of the literature suggests that early intervention is necessary for patients who have suffered from maxillofacial and cervical trauma. ${ }^{[6,10,12,14-16]}$ Similarly, we suggest that primary life-saving procedures should be performed in the operational field hospital along with a multidisciplinary evaluation of the patient and surgical procedures for hemorrhage, splint stabilization, or rigid fixation of the facial bony framework; closure of the primary soft tissue; and securing the airway. The standard $A B C$ s of trauma care should apply to the patients with maxillofacial and cervical injuries, and the primary goal of treatment for maxillofacial injuries is early conservative repair, with an emphasis on symmetrical and functional facial contours. ${ }^{[17]}$ Overall, an airway assessment is the first priority in the management of maxillofacial and cervical trauma. ${ }^{[14,18]}$ Common indications for a surgical airway intervention are massive or minimal hemorrhage, glottic edema (as observed with inhalation injuries), and maxillofacial skeletal trauma. ${ }^{[16]}$ A facial laceration repair with a soft tissue approximation was the most common head and neck procedure in our operational field hospital. Based on Brennan's ${ }^{[15]}$ study on 298 patients from the Iraq and Afghanistan conflicts, we suggest that the soft tissue can be closed immediately after extensive irrigation and conservative debridement. When the patient is hemodynamically stabilized, multidisciplinary evaluation of the patient who has suffered from trauma should be performed and comprehensive treatment plan should be made. ${ }^{[6]}$

The limitations of this study included the lack of ability to confirm the information with the radiological and operative records of patients who have suffered from maxillofacial and cervical trauma, and the effective categorization of the injuries via trauma coding systems. Data analyzed for this study showed that a few of primary records of the patients were insufficient for the forensic and medical evaluations. Moreover, there was a lack of complete data on the post-injury complications and comprehensive treatment of these patients.

\section{Conclusion}

The maxillofacial and cervical regions are the most commonly injured sites in modern conflicts, which are usually located in urban areas. Blast injuries due to IEDs, which are a form of injury sustained by HEEDs, are currently seen quite often in these conflicts. Because of the huge blast effects of these injuries, trauma scoring systems should be used for further evaluation of the patients to predict the extent of reconstructive surgery that may be required for functional and esthetic morbidity of combat-related injuries to the maxillofacial region. Early and accurate medical and surgical interventions in maxillofacial and cervical injuries secondary to HEEDs or 
LBWs may lower the rates of morbidity and subsequent disfigurement, and preserve the esthetic architecture, making future reconstruction possible.

\section{Conflict of interest: None declared.}

\section{REFERENCES}

1. Tong D, Beirne R. Combat body armor and injuries to the head, face, and neck region: a systematic review. Mil Med 2013;178:421-6. [CrossRef]

2. Dobson JE, Newell MJ, Shepherd JP. Trends in maxillofacial injuries in war-time (1914-1986). Br J Oral Maxillofac Surg 1989;27:441-50.

3. Owens BD, Kragh JF Jr, Wenke JC, Macaitis J, Wade CE, Holcomb JB. Combat wounds in operation Iraqi Freedom and operation Enduring Freedom. J Trauma 2008;64:295-9. [CrossRef]

4. Lew TA, Walker JA, Wenke JC, Blackbourne LH, Hale RG. Characterization of craniomaxillofacial battle injuries sustained by United States service members in the current conflicts of Iraq and Afghanistan. J Oral Maxillofac Surg 2010;68:3-7. [CrossRef]

5. Kosashvili Y, Hiss J, Davidovic N, Lin G, Kalmovic B, Melamed E, et al. Influence of personal armor on distribution of entry wounds: lessons learned from urban-setting warfare fatalities. J Trauma 2005;58:123640. [CrossRef]

6. Salinas NL, Brennan J, Gibbons MD. Massive facial trauma following improvised explosive device blasts in Operation Iraqi Freedom. Otolaryngol Head Neck Surg 2011;144:703-7. [CrossRef]

7. Glapa M, Kourie JF, Doll D, Degiannis E. Early management of gunshot injuries to the face in civilian practice. World J Surg 2007;31:2104-10.

8. Lawnick MM, Champion HR, Gennarelli T, Galarneau MR, D'Souza E, Vickers RR, et al. Combat injury coding: a review and reconfiguration. J
Trauma Acute Care Surg 2013;75:573-81. [CrossRef]

9. Champion HR, Holcomb JB, Lawnick MM, Kelliher T, Spott MA, Galarneau MR, et al. Improved characterization of combat injury. J Trauma 2010;68:1139-50. [CrossRef]

10. Wordsworth M, Thomas R, Breeze J, Evriviades D, Baden J, Hettiaratchy $\mathrm{S}$. The surgical management of facial trauma in British soldiers during combat operations in Afghanistan. Injury 2017;48:70-74. [CrossRef]

11. Levin L, Zadik Y, Peleg K, Bigman G, Givon A, Lin S. Incidence and severity of maxillofacial injuries during the Second Lebanon War among Israeli soldiers and civilians. J Oral Maxillofac Surg 2008;66:1630-3.

12. Breeze J, Gibbons AJ, Hunt NC, Monaghan AM, Gibb I, Hepper A, et al. Mandibular fractures in British military personnel secondary to blast trauma sustained in Iraq and Afghanistan. Br J Oral Maxillofac Surg 2011;49:607-11. [CrossRef]

13. Feldt BA, Salinas NL, Rasmussen TE, Brennan J. The joint facial and invasive neck trauma (J-FAINT) project, Iraq and Afghanistan 20032011. Otolaryngol Head Neck Surg 2013;148:403-8. [CrossRef]

14. Norris O, Mehra P, Salama A. Maxillofacial Gunshot Injuries at an Urban Level I Trauma Center-10-Year Analysis. J Oral Maxillofac Surg 2015;73:1532-9. [CrossRef]

15. Brennan J. Head and neck trauma in Iraq and Afghanistan: different war, different surgery, lessons learned. Laryngoscope 2013;123:2411-7.

16. Keller MW, Han PP, Galarneau MR, Brigger MT. Airway management in severe combat maxillofacial trauma. Otolaryngol Head Neck Surg 2015;153:532-7. [CrossRef]

17. Cunningham LL, Haug RH, Ford J. Firearm injuries to the maxillofacial region: an overview of current thoughts regarding demographics, pathophysiology, and management. J Oral Maxillofac Surg 2003;61:932-42.

18. McLean JN, Moore CE, Yellin SA. Gunshot wounds to the face-acute management. Facial Plast Surg 2005;21:191-8. [CrossRef]

\section{ORIJIINAL ÇALIŞMA - ÖZET}

\section{Maksillofasiyal ve servikal bölgelerde savaşa bağlı yaralanmaların analizi ve operasyonel saha hastanesindeki deneyimler \\ Dr. Mehmet Burak Aşık, ${ }^{1}$ Dr. Sinan Akay, ${ }^{2}$ Dr. Sami Eksert ${ }^{3}$}

${ }^{1}$ Gülhane Eğitim ve Araştırma Hastanesi, KBB ve Baş-Boyun Cerrahisi Kliniği, Ankara

${ }^{2}$ Dr. Aşkım Tüfekçi Devlet Hastanesi, Radyoloji Kliniği, Adana

${ }^{3}$ Gülhane Eğitim ve Araştırma Hastanesi, Anesteziyoloji ve Reanimasyon Kliniği, Ankara

AMAÇ: Savaşın değişen şartları ile maksillofasiyal yaralanmalar daha sık görülmeye başlandı. Özellikle kentsel alanlarda, el yapımı patlayııı gibi yüksek enerjili patlayıcı cihazlar, uzun namlulu silahların yanında sıklıkla kullanılmaktadır. Travma hastasına zamanında tıbbi ve doğru tepki verebilmek için travma puanlama sistemleri ve çok disiplinli yaklaşım kullanılması önemlidir. Bu çalısmada, uzun namlulu silahlar ya da yüksek enerjili patlayıcı cihazlar tarafından oluşan yaralanmalar arasında Askeri Yaralanma Ölçeği (MCIS) ve Askeri İşlevsellik Arızası Ölçeği (MFIS) karşılaştıııldı ve operasyonel saha hastanesinin deneyimleri paylaşıldı.

GEREÇ VE YÖNTEM: 27 Temmuz 2015 ile 22 Temmuz 2016 tarihleri arasında uzun namlulu silah (LBW) ve yüksek enerjili patlayıcılardan (HEED) kaynaklı maksillofasiyal ve servikal yaralanmaları sebebi ile operasyon hastanesine başvuran 84 hastanın tıbbi verileri gözden geçirildi. Tüm hastalar için MCIS ve MFIS skorları hesaplandı ve nitelikli hastaların kayıtları Glasgow Koma Ölçeği (GKS) skorları ve hasar alanları için değerlendirildi. Hastalar yaralanmaya neden olan cihaza/silaha göre iki gruba ayrıldı: I. grup LBW ve II. gruptaki HEED olarak belirlendi.

BULGULAR: Hastaların tümü erkekti ve yaş ortalaması 28.75 idi (20-58). Ortalama GKS skoru 13.4 iken, I6 hastada (\%।9) I5'ten düşüktü. LBW ve HEED grupları arasında MCIS skorlarında istatistiksel olarak anlamlı farklılı yoktu $(p=0.206)$. Ek olarak LBW ve HEED grupları arasında MFIS skorlarında istatistiksel olarak anlamlı farklılık yoktu $(p=0.238)$.

TARTIŞMA: Maksillofasiyal ve servikal bölge yaralanmaları, çoğunlukla kentsel alanlarda bulunan modern çatışmalara daha çok girmeye başlamıştır. Yüksek enerjili patlayıcı cihazların yol açtığı yaralanmalar, maksillofasiyal alanda uzun namlulu silahların neden olduğu yaralanmalar kadar morbid ve ölümcüldür. Hızlı ve kapsamlı müdahale, hayat kurtarıcıdır ve hastanın ileri travma tedavisine yardımcı olur.

Anahtar sözcükler: Maksillofasyal travma; travma; travma skorlama sistemi; yüksek enerjili patlayıcılar.

Ulus Travma Acil Cerrahi Derg 2018;24(1):56-60 doi: 10.5505/tjtes.2017.75333 